\title{
Extent and Rate of Changes in Landuse/Landcover Around Kaduna Refining and Petrochemical Company, Chikun Local Government, Kaduna State
}

\section{Dr. Shehu Zakari Damau', Bara'u Yakubu Usman², Prof. Maharazu Alhaji Yusuf ${ }^{3}$, Prof. Adamu Idris Tanko ${ }^{3}$}

${ }^{1}$ Kaduna Geographic Information Service (KADGIS). No. 31 Ali Akilu Road, Unguwar Sarki, PMB 2078, Kaduna, Kaduna State

${ }^{2}$ Kook Technologies Limited (KTL) No. 25, Obafemi Awolowo Road, Ikeja, Lagos

${ }^{3}$ Geography Department, Faculty of Earth and Environmental Sciences, Bayero University, Kano

\section{Article Info}

Volume 7, Issue 5

Page Number: 13-23

Publication Issue :

September-October-2020

\section{Article History}

Accepted : 01 Sep 2020

Published : 07 Sep 2020

\section{ABSTRACT}

Anthropogenic activities on land resulted in landuse/landcover change including vegetation. Landuse changes play a role in the sustainability of refinery because of associated environmental effects. Moreover, there is growing societal concern about the spatial and temporal scales of some types of conversions, such as deforestation and urbanization. This paper determine the extent and rate of changes in landuse/landcover as a result of establishment of Kaduna Refinery and petrochemical company. The study employed the used of Remote Sensing and GIS techniques in acquiring and analysing the data respectively. The 1974 Landsat 4 Multispectral Scanner (MSS) 60m resolution, 1986 Landsat 5 Thematic Mapper (TM) 30m resolution, 1999 Enhanced Thematic Mapper Plus (ETM+) 30m resolution and 2018 Landsat 8 Operational Land Imager (OLI) 30m resolution images were used. A supervised Image classification method was used because of its high accuracy. This was carried out using ArcGIS 10.5 software. The built-up areas were constantly increasing, while vegetation and agricultural land were decreasing proportionally due to clearance to make room for the industry and settlements for staff and refinery attracted population. There is need for establishment of a programs that promote tree planting, must especially the exotics ones as they are the most threatened species in the area. The present agricultural land need to be preserve and new ones need to be open and expanded in order to improve the agricultural activities of the area.

Keywords: Extent, Rate, Changes, Landuse and Landcover

\section{INTRODUCTION}

Land-use change is a change in anthropogenic activities on land, which often is characterized in part by a change in land cover, including the dominant vegetation. Land-use changes play a role in the sustainability of refinery because of associated environmental effects. Moreover, there is growing

Copyright: (C) the author(s), publisher and licensee Technoscience Academy. This is an open-access article distributed under the terms of the Creative Commons Attribution Non-Commercial License, which permits unrestricted noncommercial use, distribution, and reproduction in any medium, provided the original work is properly cited 
societal concern about the spatial and temporal scales of some types of conversions, such as deforestation and urbanization. The impacts of refinery development will depend in part on the type of land conversion, the extent (area) of land use that has changed, the intensity of land disturbance and management, and the duration of the change (for example, whether it is reversible) (Sax \& Gaines, 2003).

Commercial-scale production of oil will require substantial land area for each facility and the largescale deployment of oil will lead to conversion of lands from other existing uses. Land conversion for ponds, processing facilities, and refineries for most products will be localized, and potential land conversion for related infrastructure, such as roads and power lines to the facilities, will be more diffuse and will involve linear features (Porter, Forschner \& Blair, 2001). Land-use change for oil is more likely to involve brown fields, rangelands, deserts, scrubland, abandoned farmland, or unproductive farmland, some of which may be on coasts or in near-shore marine waters. On coasts, dredge spoil islands might be additional options for use (Poland \& McCullough, 2006).

Direct land-use change generally is defined as a direct cause-and-effect link between crude oil development and land conversion in the absence of strong external mediating factors. Direct land-use change occurs within the crude oil production pathway when land for one use is dedicated for crude oil production. However, in practice, direct land-use change from crude oil production generally is assumed to include lands used for feedstock production, processing, storage, and refining areas (Okland, 2010).

Indirect land-use change occurs when crude oil production causes new land-use changes elsewhere domestically or in another country through market- mediated effects (Osuji, 2007). Direct land-use change can result in carbon sequestration, depending on the type of land conversion and prior land use.

Natural vegetation change is a consequence of vegetation succession (Acocks, 2003). During the period of occupation by early humans, people impacted on vegetation by burning and cutting vegetation or by tilling the land and keeping livestock. As human activity increased, the natural character of landscapes changed. This pattern of disturbance by humans has escalated in recent times and there are few areas in South Africa that have been spared of human influence (Luken, 2010).

This paper determined the extent and rate of changes in landuse/landcover as a result of establishment of Kaduna Refining and Petrochemical Company with a view to providing information for proper management by the authorities.

\subsection{DESCRIPTION OF THE STUDY AREA}

The Chikun local government area of Kaduna state is located between latitude $10^{\circ}$ to $11^{\circ}$ North and longitude $7^{\circ}$ and $8^{\circ}$ East. The Kaduna refinery occupies $2.89 \mathrm{~km}^{2}$, the local government area has a total land area of $\left(41 \mathrm{~km}^{2}\right)$ of the area (figure 1). The Chikun Local Government area is initially characterized by over $80 \%$ agricultural land use. Adewuyi \& Baduku (2012) also added that about 85\% of the land is suitable for agricultural cultivation. However, owing to the Kaduna refinery, the land use pattern is fast changing. The decision to construct the third Nigeria refinery in Kaduna was taken in 1974 along with the second NNPC refinery located in Warri after the first one in Portharcourt (NNPC, 2016). Again the Kaduna Refinery was successfully commissioned by NNPC and ran at full capacity utilization (Mohammed, 2013). 
However, in the present time (2017) the activities in Chikun local government area also reflect the commercial services, transport and infrastructural facilities are present in the area such as electric power supply, pipe borne water, good roads, banks and telephone service. The soil of the study area fall within the tropical ferruginous soils, the top soils is coarse sandy loamy to clay loamy (Amadi, 2014). The area is situated within the guinea savannah vegetation zone of Nigeria. Therefore, it has a savannah grass land vegetation. The natural vegetation of this zone consists of scattered trees interspersed with tall grasses. However, human activity associated with urbanization have seriously modified the vegetation to the extent that now, trees are most often found only as ornamental ones, comprising mostly of exotic species (Adetola, 1990).

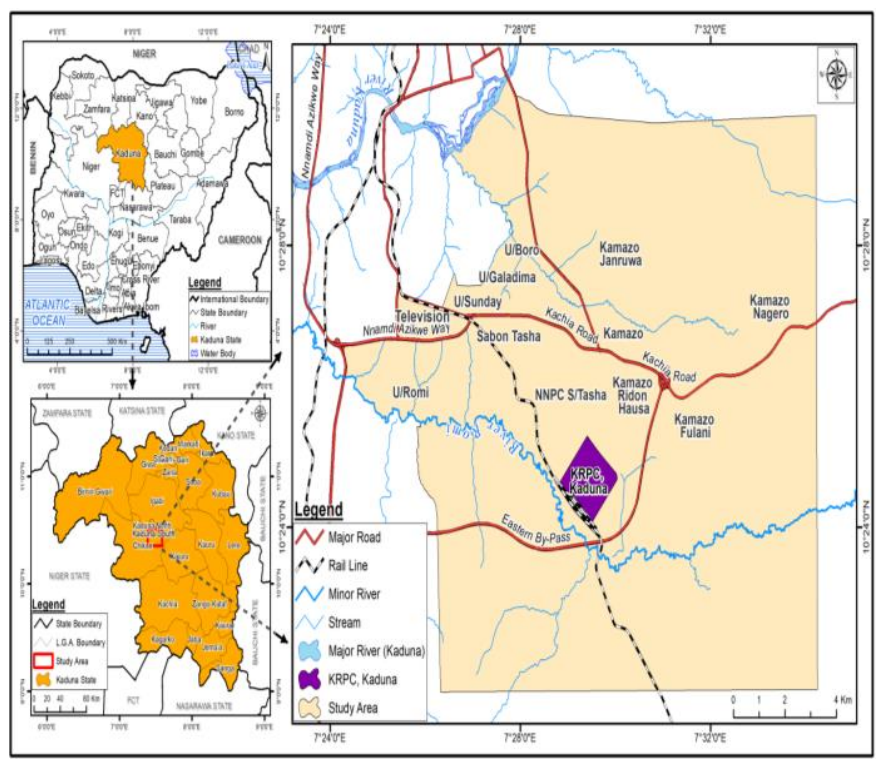

Figure1. Kaduna Refinery and the Study

Locations (communities)

Source: GIS Laboratory,

Department of Geography

(BUK, 2017)

\section{MATERIALS AND METHOD}

The data used to identify the changes in landuse/landcover in the study area and examine the impact of KRPC on natural vegetation included the following: The 1974 Landsat 4 Multispectral Scanner (MSS) 60m resolution, 1986 Landsat 5 Thematic Mapper (TM) 30m resolution, 1999 Enhanced Thematic Mapper Plus (ETM+) 30m resolution and 2018 Landsat 8 Operational Land Imager (OLI) 30m resolution were used. The images were used for classification to produce landuse/landcover classes from which built-up, natural vegetation and agricultural land were derived. This also provided the statistical data used to determine the change in landuse/landcover extents over time (Table 2). These were sourced from United States Geological Survey (USGS) Earth Explorer online portal.

Coordinates of some selected known points were collected using Global Positioning System (GPS) in order to aid the classification process. These were sourced from direct field measurement using a handheld GPS.

\subsubsection{Image Acquisition and Analysis}

For the purpose of this study, Toposheet and satellite maps were acquired from the survey Department, Kaduna State Ministry of Lands. These were used to identify the land use types and land cover based on satellite image, slope, altitude and other physical features on the surface. However, Lillesland and Kiefer (1999) pointed that acquisition of Google earth image is guided by spatial location.

\subsubsection{Image Processing for Landuse and Vegetation}

Pre-processing which involved geometric corrections and removing all distortions in positions and radiometric corrections which remove distortions resulting from reflection was carried out. A subset of the study area was extracted from the large image. Resampling was also carried out to reduce and align the pixel value of the 1974 Multispectral Scanner 
(MSS) 60m resolution with that of 1986 Landsat 5 Thematic Mapper (TM) 30m resolution, 1999 Landsat Enhanced Thematic Mapper Plus (ETM+) 30m resolution and the 2018 Landsat 8 Operational Land Imager (OLI) $30 \mathrm{~m}$ resolution. These were carried out using ArcGIS 10.5 software.

\subsubsection{Classification}

Image pixels were grouped in different landuses as outlined in the classification scheme in table 1 through a process called classification. A supervised classification method was used because of its high accuracy (Njoku, 2000). This was carried out using ArcGIS 10.5 software.

Table 1: Land Use Classification Scheme

\begin{tabular}{lll}
\hline S/No. & $\begin{array}{c}\text { Land Use/ Land } \\
\text { Cover Type }\end{array}$ & \multicolumn{1}{c}{ Interpretation } \\
\hline \multirow{3}{*}{ Built-up Area } & Villages, Urban Areas, \\
& Open \\
& Spaces/Recreational \\
& Areas, Commercial \\
& Areas, Vacant Lands, \\
& Institutional Areas \\
& Shrub/Grassland, Forest \\
& Vegetation & cover, \\
& & Vegetation \\
& & Actively Cultivated \\
& & Lands, Uncultivated \\
& Agricultural Land & Farm Lands, Rain fed \\
& & Agricultural Lands, \\
& & Irrigation Agricultural \\
& & Lands, Orchard/Fruit \\
& & Trees, Orchard/Fadama \\
\hline &
\end{tabular}

Source: Adapted and Modified from Njoku, (2000).

\subsubsection{Identifying the Annual Rate of Changes Landuse/Landcover (1974-2018)}

Identifying the changes that have taken place (over the last forty Four years) in the landuses was performed in Excel after copying the area (in square kilometers) of each landuse / landcover calculated in ArcGIS. This involved three steps. According to Njoku, 2000.

i. Calculating the change (magnitude of change),

ii. Percentage change

iii. Calculating the annual rate of change.

\subsubsection{Magnitude of Change}

Calculating the magnitude of change involved subtracting the area of the beginning year from that of the end year as shown in the equation presented in equation 1 .

$$
C=E-B
$$

Where : $\mathrm{C}=$ Change

$\mathrm{E}=$ Area of the End year

$\mathrm{B}=$ Area of the Beginning year

For example, the magnitude (extent) of change of built-up from 1974-1986 was calculated as follows:

Area of End year $(2003)=26.97$

Area of Beginning year $(1990)=10.70$

Change (Magnitude of change $)=26.97-10.70=16.27$

\subsubsection{Percentage change}

Percentage change was calculated by subtracting the beginning year from the end year divided by the beginning year and multiplied by 100 as shown in the equation 2.

$$
\% C=\left(\frac{E-B}{B}\right) 100
$$

Where $\% \mathrm{C}=$ Percentage Change, $\mathrm{E}=$ Area of the End year, $\mathrm{B}=$ Area of the Begin year. For example, 
percentage change of built-up from 1974-1986 was calculated as follows:

End year $(1986)=26.97 \mathrm{Km}^{2}$

Beginning year $(1974)=10.70 \mathrm{Km}^{2}$

Therefore percentage change $=26.97-10.70 / 26.97 \mathrm{X}$ $100=152.01 \%$

\subsubsection{Annual rate of change}

In calculating the annual rate of change, the change was divided by the number of study years (the difference between the two years) as shown in equation 3 .

$$
\mathrm{AROC}=\frac{\mathbf{E}-\mathrm{B}}{\mathbf{N}}
$$

Where AROC = Annual Rate of Change

$$
\begin{aligned}
& E=\text { Area of the End year } \\
& B=\text { Area of the Begin year } \\
& N=\text { Number of the Study years }
\end{aligned}
$$

For example, the Annual rate of change of built-up area from 1974-1986 was calculated as follows:

End year $(1986)=26.97 \mathrm{Km}^{2}$

Beginning year $(1974)=10.70 \mathrm{Km}^{2}$

Number of years (between 1974 and 1986) = 13

Therefore, the Annual rate of change $=26.97-10.70=$ $16.27 / 13=2.01 \mathrm{Km}^{2}$

\subsubsection{Examining the Impact of KRPC on Vegetation}

Examining the Impact of KRPC on Vegetation involved mapping out the boundary of KRPC from Google Earth as a KML file and converting it to a feature class. The vegetation class was extracted and converted to a single feature class layer. The clip analysis tool in ArcGIS 10.5 was used to clip out the portion of vegetation in 1974 that is overlaid by present KRPC boundary. The tool to cut out a piece of vegetation 1974 class using KRPC feature class as a cookie cutter. This was particularly useful for creating a new feature class which represented the vegetation in 1974 impacted on by building of the industry. The calculate geometry tool in ArcGIS 10.5 was used to calculate the area of the clipped out vegetation in $\mathrm{Km}^{2}$. This gave the amount of vegetation that was remove to make room for the industry. Maps were produced to show this impact (Musa, 2015).

\subsubsection{Spatial Data Analysis Methods}

GIS tools were used to analyse landsat images of different landuse, landcover and vegetation changes over 44 years (1974-2018). This information helps to discover changes in land used and vegetation. The causes and consequences of the changes have been considered and appropriate statistical techniques were used. This satellite images of the Kaduna refinery for the last 44 years (1974-2018) were analysed using GIS tools. All these acquired images are located at the same period of November to December and are about the same resolutions (situated between 30,30 to $30 \mathrm{~m}$ ) except the image of 1974 which has a resolution of $60 \mathrm{~m}$.

Table 2: Resolution of Satellite Image (1974-2018)

\begin{tabular}{ll}
\hline Years & Resolution $(\mathrm{m})$ \\
\hline 1974 & 60 \\
1986 & 30 \\
1999 & 30 \\
2018 & 30 \\
\hline
\end{tabular}

Sources: field work, 2018

\section{RESULT AND DISCUSSION}

\subsubsection{Extent and Changes}

The extent of landuse/landcover ascertained that built-up areas occupied $8.93 \mathrm{Km}^{2}(6.11 \%)$ in 1974 subsequently increased to $78.62 \mathrm{Km}^{2}(53.75 \%)$ in 2018. Vegetation occupied $61.88 \mathrm{Km}^{2}(42.31 \%)$ in 1974 and has reduced to $12.38 \mathrm{Km}^{2}(8.46 \%)$ in 2018 . Agricultural land which had initially occupied 
$75.45 \mathrm{Km}^{2}$ (51.59\%) in 1974 declined to $55.26 \mathrm{Km}^{2} \quad$ (37.78\%) in 2018 (Table 3 \& Figure 2).

Table 3: Extent of Landuse/Landcover (1974-2018).

\begin{tabular}{ccccccccc} 
& $\mathbf{1 9 7 4}$ & \multicolumn{2}{c}{$\mathbf{1 9 8 6}$} & \multicolumn{2}{c}{$\mathbf{1 9 9 9}$} & \multicolumn{2}{c}{$\mathbf{2 0 1 8}$} \\
Land Use & $\mathbf{K m}^{2}$ & Percentage & $\mathbf{K m}^{2}$ & Percentage & $\mathbf{K m}^{2}$ & Percentage & $\mathbf{K m}^{2}$ & Percentage \\
\hline $\begin{array}{c}\text { Built-up } \\
\text { Area }\end{array}$ & 8.93 & $6.11 \%$ & 22.78 & $15.58 \%$ & 45.34 & $31.00 \%$ & 78.62 & $53.75 \%$ \\
$\begin{array}{c}\text { ural } \\
\text { Vegetation }\end{array}$ & 61.88 & $42.31 \%$ & 52.72 & $36.04 \%$ & 38.16 & $26.09 \%$ & 12.38 & $8.46 \%$ \\
$\begin{array}{c}\text { Agricultural } \\
\text { Land }\end{array}$ & 75.45 & $51.59 \%$ & 70.76 & $48.38 \%$ & 62.76 & $42.91 \%$ & 55.26 & $37.78 \%$ \\
\hline Total & $\mathbf{1 4 6 . 2 6}$ & $\mathbf{1 0 0 . 0 0 \%}$ & $\mathbf{1 4 6 . 2 6}$ & $\mathbf{1 0 0 . 0 0 \%}$ & $\mathbf{1 4 6 . 2 6}$ & $\mathbf{1 0 0 . 0 0 \%}$ & $\mathbf{1 4 6 . 2 6}$ & $\mathbf{1 0 0 . 0 0 \%}$ \\
\hline
\end{tabular}

Source: Field and Laboratory Analysis, 2018

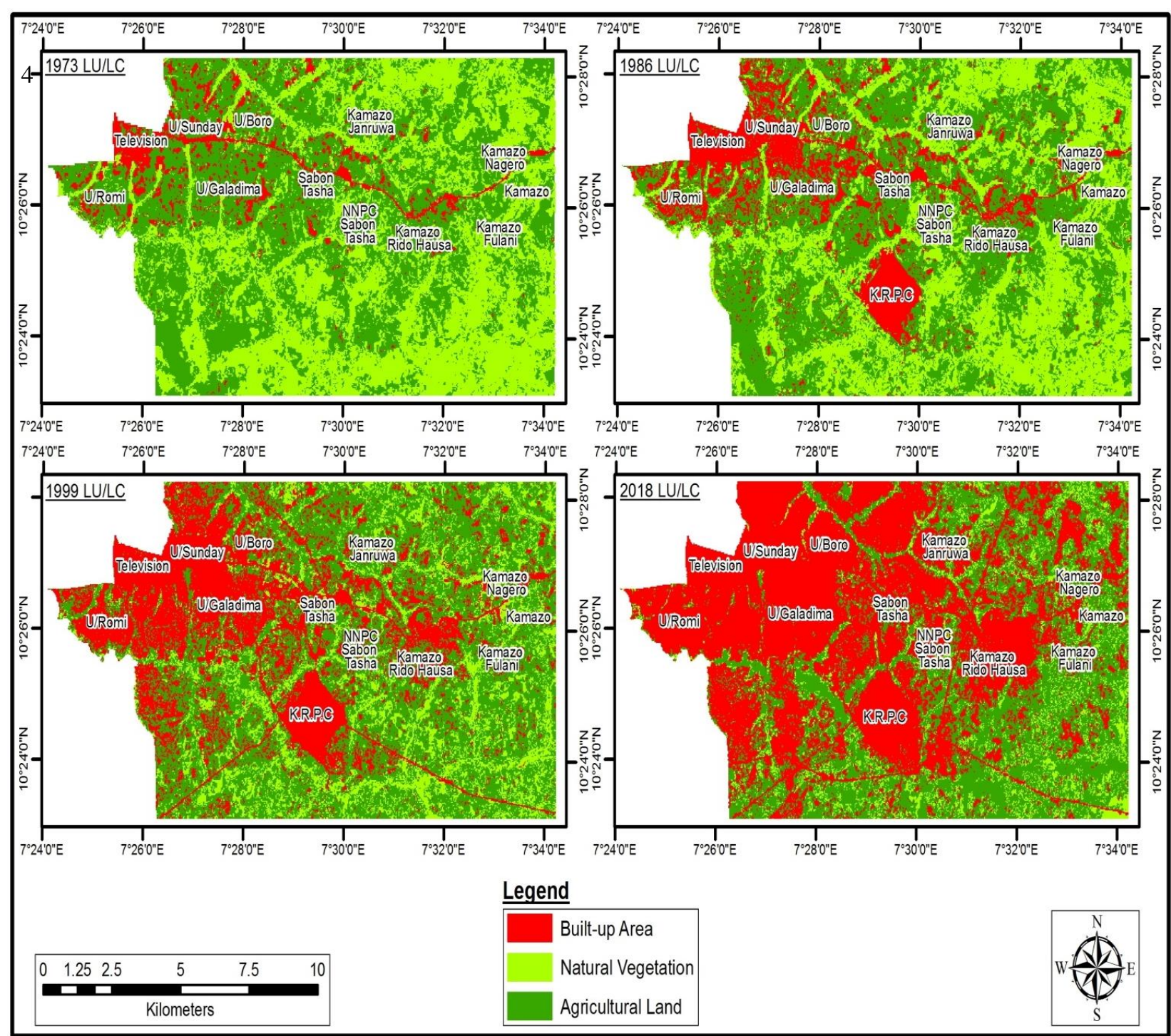

Figure 2: Changes in Landuse/Landcover

Source: Field and Laboratory Analysis, 2018 


\subsubsection{Rate and Changes in Landuse/Landcover}

Landuse/Landcover around Kaduna Refinery and Petrochemical Company before and after the establishment of the industry (1974-2018) shows considerable changes. The built-up areas has undergone dramatic changes from 1974 to 2018. A change (increase) in built-up area of $13.85 \mathrm{Km}^{2}$ $(154.99 \%)$ at per-annual rate of $1.07 \mathrm{Km}^{2}(11.92 \%)$ was experienced in the period 1974-1986. The period of 1986-1999 has also seen an increase in built-up area of $22.56 \mathrm{Km}^{2}(99.01 \%)$ at per annual rate of $1.75 \mathrm{Km}^{2}$ (7.62\%). An increase in built-up area of $33.28 \mathrm{Km}^{2}$ $(73.40 \%)$ at per annual rate of $1.75 \mathrm{Km}^{2}(3.86 \%)$ was observed within the period of 1999-2018. However, in the overall period of 1974-2018, built-up area has changed (increased) to $69.69 \mathrm{Km}^{2}(779.93 \%)$ at an annual rate of $1.55 \mathrm{Km}^{2}(17.33 \%)$ (Table 4$)$.

The increase in built-up area from 1974 to 2018 around KRPC must have resulted from citing of the refinery in the area coupled with population growth which necessitated the need to build residential areas to house the growing population of industrial workers. Road and rail development leading to KRPC must have also led to the development of linear settlement along the routes. Moreover, the development of NNPC quarter at Sabon Tasha to house the workers of KRPC must have also led to the increase in built-up area in the study area. This result however, corresponds with the findings of Akpu et al. (2017), in a study of the rate and pattern of the spatiotemporal growth of Kaduna metropolis from 1973-2009 and found that the southern part of the River Kaduna (where KRPC is located) was growing at a higher rate (11.24\%). Also, Afon and Alwadood (2016) who studied the growth of Kaduna metropolis between 1973 and 2012 and its physical planning implications also found that the built-up area had experienced 13.4\% growth rate per annum. Vegetation has also undergone a change (decrease) of $-49.50 \mathrm{Km}^{2}(-$ $80.00 \%)$ at an annual rate of $-1.10 \mathrm{Km}^{2}(-1.78 \%)$ in the period of 1974-2018.

With respect to agricultural land, the period 19741986 has witnessed a decrease in agricultural land of $4.69 \mathrm{Km}^{2}(-6.22 \%)$ at $0.36 \mathrm{Km}^{2}(0.48 \%)$ per annum. Agricultural land has decreased by $-8.00 \mathrm{Km}^{2}$ ($11.31 \%)$ at an annual rate of $-0.62 \mathrm{Km}^{2}(-0.89 \%)$ in the period of 1986-1999. The period of 1999-2018 also witnessed a decrease of $-7.50 \mathrm{Km}^{2}(-11.95 \%)$ at $0.39 \mathrm{Km}^{2}(-0.62 \%)$ annually. However, within the overall period of 1974-2018, agricultural land has decreased by $-20.19 \mathrm{Km}^{2}(-26.76 \%)$ at a rate of $0.45 \mathrm{Km}^{2}(-0.59 \%)$ every year (Table 4$)$. This decrease must have resulted from the conversion of farm lands to residential areas in order to meet the residential demand of the growing population. This result correlate with the findings of Saleh, et al. (2014), who in his study of agricultural change and disappearance of farmlands in Kaduna Metropolis found that the study area experienced a significant reduction in agricultural land and these leads to continued disappearance of farmlands. 
Table 4: Rate of Changes in Land use / Land cover before and after the Establishment of KRPC (1974-2018)

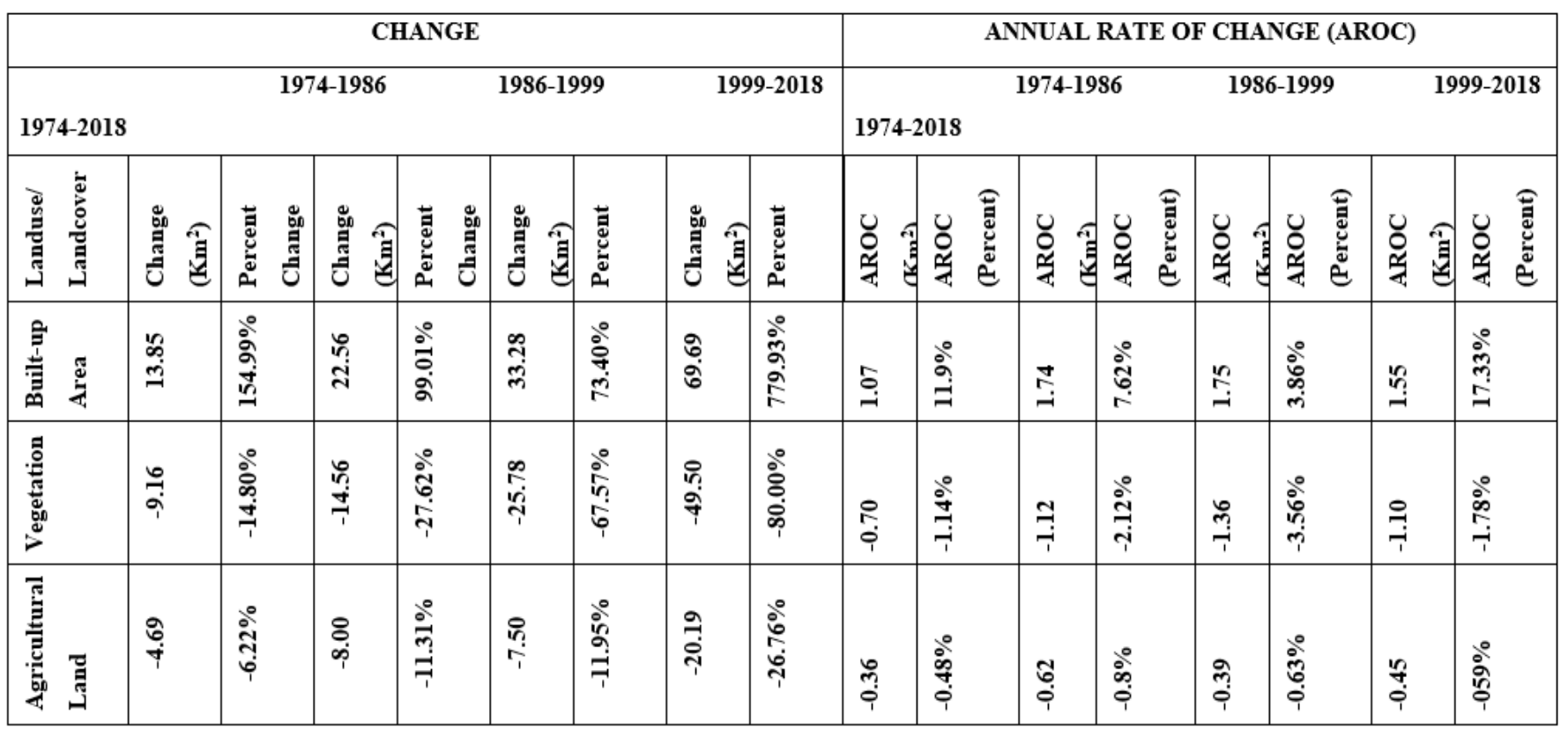

Source: Field and Laboratory Analysis, 2018

Key: AROC: Annual Rate of Change

\subsection{IMPACT OF KADUNA REFINERY PETRO-CHEMICAL COMPANY ON VEGETATION}

As a result of the establishment of KRPC, vegetation has experienced tremendous lost in extent and rate. The period 1974-1986 has witnessed a loss of $-9.16 \mathrm{Km}^{2}(-14.80 \%)$ in vegetation at a rate of $-0.70 \mathrm{Km}^{2}(-1.14 \%)$ per annum. The period between 1986 and 1999 had natural vegetation loss of $-14.56 \mathrm{Km}^{2}(-27.62 \%)$ at a rate of $1.12 \mathrm{Km}^{2}(-2.12 \%)$ per year. A loss of $-25.78 \mathrm{Km}^{2}(-67.57 \%)$ in vegetation at an annual rate of $-1.36 \mathrm{Km}^{2}(-3.56 \%)$ was witnessed between 1999 and 2018. However, the overall period between 1974 and 2018 has seen a lost in vegetation of $-49.50(-80.00 \%)$ at $-1.10(-1.78 \%)$ annually (Table 5 and figure 3$)$.

Table 5: The Impact (Extent and Rate of Change in Vegetation) of KRPC on Vegetation

\begin{tabular}{|c|c|c|c|c|c|c|}
\hline \multicolumn{3}{|c|}{ IVegetation } & \multicolumn{2}{|c|}{ Extent of Change } & \multicolumn{2}{|c|}{ Rate of Change } \\
\hline Period & Year & $\mathbf{K m}^{2}$ & $\mathbf{K m}^{2}$ & Percentage & $\mathrm{Km}^{2} /$ Year & Percentage /Year \\
\hline 1974-1986 & 1974 & 61.88 & -9.16 & $-14.80 \%$ & -0.70 & $-1.14 \%$ \\
\hline (13Years) & 1986 & 52.72 & & & & \\
\hline 1986-1999 & 1986 & 52.72 & -14.56 & $-27.62 \%$ & -1.12 & $-2.12 \%$ \\
\hline (13Years) & 1999 & 38.16 & & & & \\
\hline $1999-2018$ & 1999 & 38.16 & -25.78 & $-67.57 \%$ & -1.36 & $-3.56 \%$ \\
\hline (19Years) & 2018 & 12.38 & & & & \\
\hline 1974-2018 & 1974 & 61.88 & -49.50 & $-80.00 \%$ & -1.10 & $-1.78 \%$ \\
\hline (45Years) & 2018 & 20.59 & & & & \\
\hline
\end{tabular}

Source: Field and Laboratory Analysis, 2018 


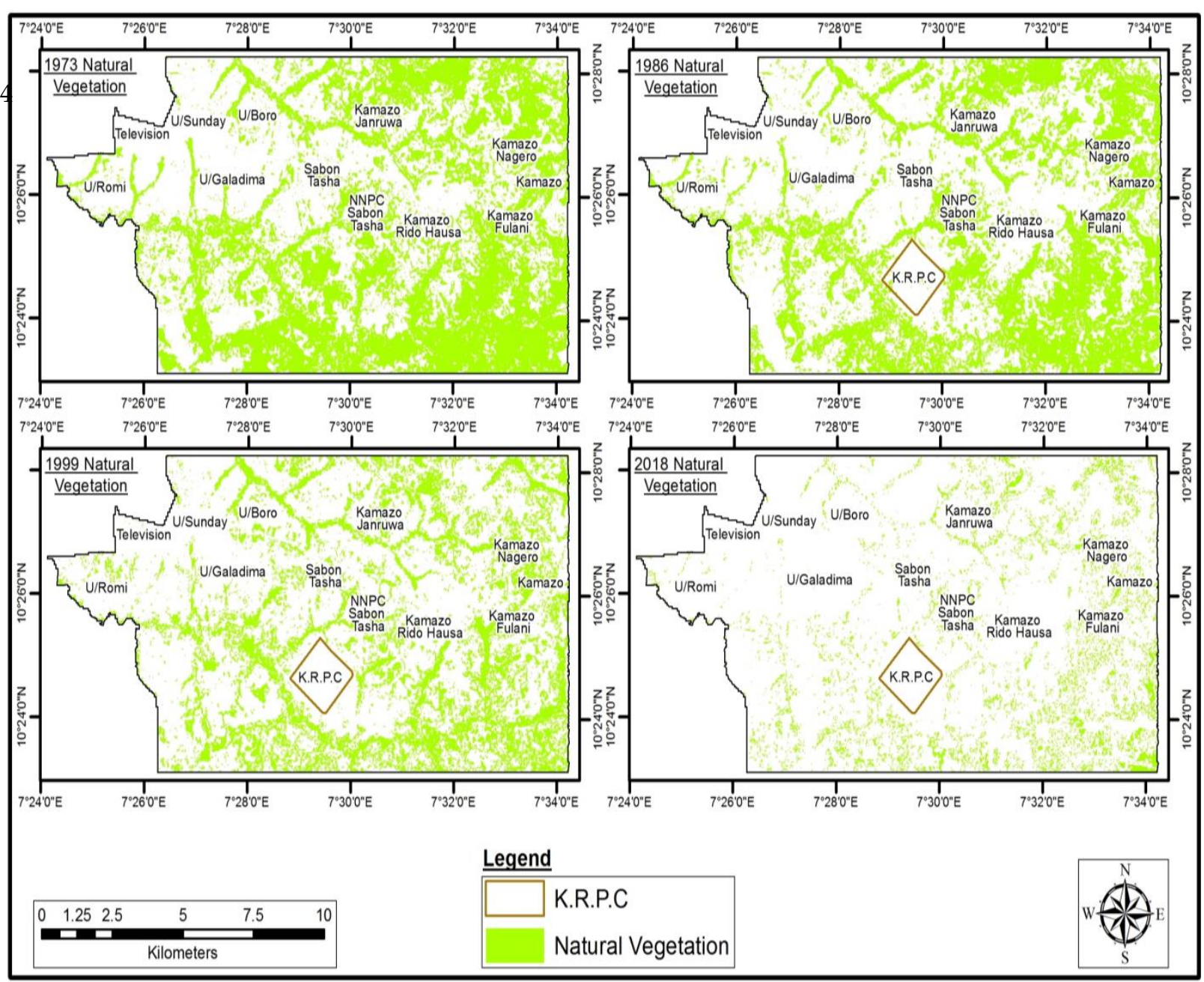

Figure 3: Impact of KRPC on Vegetation

Source: Field and Laboratory Analysis 2018

The reduction in vegetation, crop land, increase in built-up areas and other land use changes are attributed to the establishment of the refinery. It is understandable that there is chronological increase in population generally in Kaduna but the areas around the Kaduna Refinery and Petrochemical Company is unique especially when considering the dynamics and changes in social and cultural composition of the people residing in these areas. Thus comparing this findings with the work of Akpu, et al. (2017) where the rate was only $-2.3 \%$ per annum with the current research showing $-49.50 \%$, it implies the vegetation is decreasing at a rapid rate. This decrease could be as a result of the establishment of KRPC which led to clearance of vegetation to build the industry and residential areas around the industry. Population explosion which leads to demand for residential areas and consequent clearance of vegetation to build houses and for fire wood conversion of native vegetation to farm land could also be attributed to the decrease in vegetation. The replacement of native vegetation by infrastructure (for example, buildings or roads) could also be responsible for the depletion of vegetation. For example, the construction of roads such as the eastern bye pass could also be responsible for the disappearance of vegetation. 
This result was supported by the work of Akpu, et al (2017) who stated that $81.8 \%$ of the vegetation cover was lost at an annual rate of $-2.3 \%$. The result is also in agreement with the work of Musa (2014) in the analysis of land use and land cover change in southern part of Kaduna metropolis, which revealed that vegetation had decreased by $48.13 \%$ between 1990 and 2014 (Rate of -2.3\%). Also Abubakar, Olowolafe and Obansa (2012) in their study of the land use and land cover change analysis along river Kaduna floodplain using geospatial techniques found that the trend of change indicated a progressive conversion of vegetation areas into farmlands and finally into built up lands. Moreover, the increase for more residential lands was as a result of the increasing population of the communities and consequently clearance of vegetation. In addition, the clearance of the land for the provision of infrastructures like roads, also aggravated that rate of vegetation decrease.

\section{IV.CONCLUSION AND RECOMMENDATIONS}

The used of GIS and Remote Sensing Techniques in examining landuse and vegetation changes before and after the establishment of KRPC in the study area showed that, the built-up areas were constantly increasing, while vegetation and agricultural land were decreasing proportionally due to clearance to make room for the industry and settlements. The result showed that, the KRCP impacted on vegetation, as a result of the establishment of Kaduna Refinery in the study area. This shown that the agriculture and vegetation cover of the area is under menace which, in turn brings unfavourable environmental condition as a result vegetation deterioration. The decrease in agricultural land also result to the decrease in local agricultural products for commercial and local consumption.

There is need for establishment of a programs that promote tree planting, must especially the exotics ones as they are the most threatened species in the area.

The present agricultural land need to be preserve and new ones need to be open and expanded in order to improve the agricultural activities of the area.

\section{REFERENCES}

[1]. Abubakar A. J., Olowolafe, E. A., Obansa Y. M. (2012) Land Use and Land Cover Change Analysis along River Kaduna Floodplain Using Geospatial Techniques. IIARD International Journal of Geography and Environmental Management Vol. 1 No. 8 ISSN 2505-8821.

[2]. Acocks K.W, (2003) The Role of Land Use Practice in Environmental Degradation in Alvu subcounty, Terego county, Arua district, Uganda. Unpublished dissertation, Makerere University, Kampala, Uganda.

[3]. Adewuyi, T.A. and Baduku, A.S. (2012) Recent Consequences of Land Degradation on Farmland in the peri-urban area of Kaduna Metropolis, Nigeria. Journal of Sustainable Development in Africa 14(3):179-193.

[4]. Akpu, B, Tanko, A. I., Jeb, D. N. and Dogo, B. (2017) Geospatial Analysis of Urban Expansion and Its Impact on Vegetation Cover in Kaduna Metropolis, Nigeria. Asian Journal of Environment \& Ecology 3(2): 1-11, 2017; Article no.AJEE.31149

[5]. Amadi N.O. (2014). Quality Assessment of Soil and Ground Water near Kaduna Refinery and Petro-chemical Company, North West Nigeria. Journal of Scientific research and Reports 3(6): 884-893, 2014; Article No. JSRR.2014.010.

[6]. Luken, O. (2010) Shell Sees Rise in Crude Theft in Nigeria. Dow Jones News wire. www.businessfox.com/news/2010/3/4

[7]. Muhammad A.A (2013). Energy Production and Environmental Concerns in Nigeria: The 
Case of Kaduna Petroleum Refinery on its Host Community. Journal of Energy Technologies and Policy.Vol.3, No.10, 2013.

[8]. Musa, I. G. (2014) Analysis of Land Use and Land Cover Change in Southern Part of Kaduna Metropolis, Kaduna State, Nigeria. M.Sc. Thesis, Geography Department Ahmadu Bello University, Zaria.

[9]. National Nigerian Petroluem Cooperation (NNPC) (2016) Oil production. Available at http://www.nnpcgroup.com/nnpcbusiness/upstr eamventures/oilproduction. aspx assessed on 20th April, 2017.

[10]. Njoku, J. D. (2000) A Multi-band Assessment of SPOT Imaging System for Land and Land Cover Mapping of Northwestern Nigeria. Unpublished MSc Thesis. Dept of Geography and Planning, University of Lagos, Akoka, Lagos.

[11]. Okland, R. H. (2010) Vegetation ecology: theory, methods and applications with reference to Fennoscandia. Sommerfeltia Suppl. 1:1-230.

[12]. Osuji, L.C. (2007) An appraisal of the impact of petroleum hydrocarbons on soil fertility: The Owaza experience. Afr. J. Agric. Res., 2: 318324.

[13]. Poland, T.M., and McCullough, D. G. (2006) Emerald ash borer: Invasion of the urban forest and the threat to North America's ash resource. Journal of Forestry 104(3):118-124.

[14]. Porter, E.E., B.R. Forschner, and Blair, R.B. (2001) Woody Vegetation and Canopy Fragmentation along Forest-Urban Gradient. Urban Ecosystems 5(2):131-151.

[15]. Saleh, Y., Badr, A.M., El Banna, F., and Shahata, A., (2014) Agricultural Change and Disappearance of Farmlands in Kaduna Metropolis. Science World Journal, Vol. 9 (No. 1).

[16]. Sax, D.F., and Gaines, S.D. (2003) Species diversity: from global decreases to local increases. Trends in Ecology \& Evolution 18(11):561-566.

\section{Cite this article as :}

Dr. Shehu Zakari Damau, Bara'u Yakubu Usman, Prof. Maharazu Alhaji Yusuf, Prof. Adamu Idris Tanko, "Extent and Rate of Changes in Landuse/Landcover Around Kaduna Refining and Petrochemical Company, Chikun Local Government, Kaduna State", International Journal of Scientific Research in Science and Technology (IJSRST), Online ISSN : 2395-602X, Print ISSN : 2395-6011, Volume 7 Issue 5, pp. 13-23, September-October 2020. Available at doi $\quad$ : https://doi.org/10.32628/IJSRST20752 Journal URL : http://ijsrst.com/IJSRST20752 